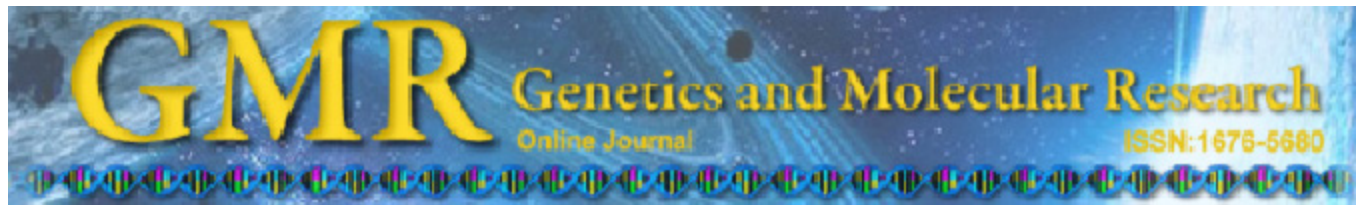

\title{
Evaluation of mutagenic, teratogenic, and immunomodulatory effects of Annona nutans hydromethanolic fraction on pregnant mice
}

\author{
C.A. Gonçalves ${ }^{1,2}$, N.L. Silva ${ }^{3}$, M.O. Mauro ${ }^{4}$, N. David ${ }^{1,2}$, \\ A.L. Cunha-Laura ${ }^{2}$, S.A. Auharek ${ }^{2,5}$, A.C.D. Monreal ${ }^{6}$, M.C. Vieira ${ }^{7}$, \\ D.B. Silva ${ }^{8}$, F.J.L. Santos ${ }^{3}$, J.M. Siqueira ${ }^{3,9}$ and R.J. Oliveira ${ }^{1,2,9}$
}

${ }^{1}$ Centro de Estudos em Células-Tronco, Terapia Celular e Genética Toxicológica, Núcleo de Hospital Universitário, Universidade Federal de Mato Grosso do Sul, Campo Grande, MS, Brasil

${ }^{2}$ Programa de Mestrado em Farmácia, Centro de Ciências Biológicas e da Saúde, Universidade Federal de Mato Grosso do Sul, Campo Grande, MS, Brasil

${ }^{3}$ Campus Centro-Oeste Dona Lindu, Universidade Federal de São João Del-Rei, Divinópolis, MG, Brasil

${ }^{4}$ Programa de Doutorado em Biotecnologia e Biodiversidade,

Rede Pró Centro-Oeste, Universidade Federal de Mato Grosso do Sul, Campo Grande, MS, Brasil

${ }^{5}$ Universidade Federal dos Vales do Jequitinhonha e Mucuri, Teófilo Otoni, MG, Brasil

${ }^{6}$ Centro de Ciências Biológicas e da Saúde,

Universidade Federal de Mato Grosso do Sul, Campo Grande, MS, Brasil

${ }^{7}$ Faculdade de Ciências Agrárias, Universidade Federal da Grande Dourados, Dourados, MS, Brasil

${ }^{8}$ Faculdade de Ciências Farmacêuticas de Ribeirão Preto, Universidade de São Paulo, Ribeirão Preto, SP, Brasil

${ }^{9}$ Programa de Pós-Graduação em Saúde e Desenvolvimento na Região Centro-Oeste, Faculdade de Medicina "Dr. Hélio Mandetta",

Universidade Federal de Mato Grosso do Sul, Campo Grande, MS, Brasil

Corresponding author: R.J. Oliveira

E-mail: rodrigo.oliveira@ufms.br

Genet. Mol. Res. 13 (2): $4392-4405$ (2014)

Received August 20, 2013

Accepted December 2, 2013

Published June 11, 2014

DOI http://dx.doi.org/10.4238/2014.June.11.3 


\begin{abstract}
Plants such as Annona nutans used in folk medicine have a large number of biologically active compounds with pharmacological and/or toxic potential. Moreover, pregnant women use these plants indiscriminately, mainly in the form of teas, without being aware of the harm that they could cause to the health of the embryo/fetus. Therefore, it is necessary to analyze the potential toxic effects of medicinal plants during gestation. The present study aimed to evaluate the effects of $A$. nutans hydromethanolic fraction leaves (ANHMF) on mutagenic and immunomodulatory activity, reproductive performance, and embryo-fetal development in pregnant female mice. The animals ( $\mathrm{N}=50$ female and 25 male) were divided into 5 groups: Control, Pre-treatment, Organogenesis, Gestational, and Pre+Gestational. The results indicate that ANHMF mainly contains flavonoid and other phenolic derivatives. It was found that it does not exhibit any mutagenic or immunomodulatory activity, and it does not cause embryo-fetal toxicity. Based on the protocols used in the present studies, our analyses confirm that it is safe to use ANHMF during pregnancy.
\end{abstract}

Key words: Annonaceae; Toxicity; Teratogenicity; Micronucleus; Immunomodulation

\title{
INTRODUCTION
}

Annonaceae is a large family that contains trees and shrubs with edible and aromatic fruits. This family contains 120 genera, and more than 2000 species. Annona is one of the most important genera in this family, with c.a. 120 species (Lebeouf et al., 1980). Phytochemical analyses of plants from the Annonaceae family have indicated the presence of terpenes, flavonoids, phenolic compounds, alkaloids (Zhang et al., 2004), and acetogenins (Yuan et al., 2006). Infusions and decoctions made of plant extracts are widely used as herbal medicines worldwide. However, herbal tea made from the leaves of Annona has been shown to induce a typical parkinsonism syndrome that is associated with the presence of acetogenins, such as annonacin (Champy et al., 2004). In addition, some studies have shown that different species of Annona, such as A. squamosa, cause anti-ovulatory and abortive activity in females (Vohora et al., 1975; Mishra et al., 1979).

In general, pregnant women use medicinal plants indiscriminately based on the assumption that they are natural products and could not cause harmful effects to the fetus (Gonçalves et al., 2013). However, plants contain compounds that might not be beneficial to the organism, by producing toxins that might negatively affect the pregnant mother or the offspring (Lapa et al., 2004). These effects might occur directly or indirectly in the cell, through interference with the mitotic process, intercellular interactions, enzyme biosynthesis, gene expression modulation, cellular $\mathrm{pH}$, osmotic balance, extracellular matrix, tissue growth, and by the control of DNA methylation (Welsch, 1992). It has been well established in the literature that these mechanisms are associated with chromosomal abnormalities, malformations, reabsorption, abortion, disruption of implantation of the conceptus, retarded intrauterine growth, functional deterioration of the newborn (including behavioral abnormalities or cognitive impairment), and embryo-fetal death (McElhatton, 1999). 
Therefore, studies are necessary to investigate the safety and efficacy of plants used in traditional (or folk) medicine, as these plants could be teratogenic, placing the health of pregnant women and their fetuses in danger. Thus, the present study evaluated the effects of $A$. nutans hydromethanolic fraction leaves (ANHMF) on the mutagenic and immunomodulatory activity, reproductive performance, and embryo-fetal development of Swiss mice.

\section{MATERIAL AND METHODS}

\section{Extract and fraction preparation}

The leaves of $A$. nutans R. E. Fr. were collected in Porto Murtinho, Mato Grosso do

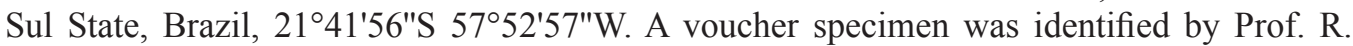
Mello Silva, and deposited (number 27648) in the CGMS Herbarium (Campo Grande, MS).

The air-dried, powdered leaves of $A$. nutans (283 g) were subjected to exhaustive extraction by percolation in methanol. The resulting extract was concentrated in vacuo to dryness $(65.89 \mathrm{~g})$. The residue was solubilized in methanol:water $(9: 1)$, which was then partitioned. The partitioning process generated hexane $(5.34 \mathrm{~g}, 8.31 \%)$, chloroform $(1.85 \mathrm{~g}, 2.84 \%)$, ethyl acetate $(6.49 \mathrm{~g}, 9.98 \%)$, and hydromethanolic $(36.88 \mathrm{~g}, 56.70 \%)$ fractions.

The hydromethanolic crude extract (HCE) and its fractions were analyzed by thin layer chromatography (TLC) on silica gel (eluent, $\mathrm{CHCl}_{3}: \mathrm{MeOH}, 8: 2$ ). These samples were compared by TLC using standard quercetin derivatives and chlorogenic acid available in the laboratory (quercetin, quercetin-3-O- $\beta$-glucoside, quercetin-3- $O$ - $\beta$-galactoside, and quercetin3-O- $\beta$-rutinoside).

The plates were sprayed with $1 \%$ methanolic acid- $\beta$-ethylamino ester (diphenylboryloxyethylamine, NP), followed by 5\% ethanolic polyethylene glycol-400 (PEG), and then exposed under UV 254 and $365 \mathrm{~nm}$ lamps. In particular, flavonoids were detected, which have a similar structure to quercetin derivatives, based on the appearance of yellowish-orange spots as described in the published literature (Wagner and Bladt, 2001).

\section{Total flavonoid quantification in ANHMF compared to quercetin equivalents}

Because there was evidence of the presence of quercetin derivatives in ANHMF, the quantification of flavonoids was carried out by spectrophotometric analysis using UV/Vis apparatus at $425 \mathrm{~nm}(\mathrm{~N}=3)$. The analyses were performed by comparing assays of total flavonoids with equivalent quercetin standards (Banov et al., 2006).

\section{Linearity}

The linearity of the method was evaluated by using calibration curves. This analytical curve was developed using quercetin standard stock solution (Q4951-10G, Sigma-Aldrich Co., St Louis, MO, USA) at a concentration of $500 \mu \mathrm{g} / \mathrm{mL}$ in methanol solution with $5 \%$ acetic acid (v/v). Dilutions at concentrations of 2.6, 3.5, 4.4, 5.3, 6.2, 7.1, 8.0, 8.9, 9.3, and $10.7 \mu \mathrm{g} /$ $\mathrm{mL}$ with $2.0 \mathrm{~mL}$ aluminum chloride $2 \%(\mathrm{w} / \mathrm{v})$ were prepared from the stock solution. The measurement of each concentration was repeated in triplicate, from which the equation of the line and linear correction coefficient was obtained (Banov et al., 2006). 


\section{Sample preparation}

The ANHMF stock solution was made from $250 \mathrm{mg}$ sample that was solubilized in 10 $\mathrm{mL}$ methanolic solution with $5 \%$ acetic acid. The solution was transferred to a $25 \mathrm{~mL}$ volumetric flask, and was then used to prepare additional dilutions (Banov et al., 2006).

\section{Accuracy}

The accuracy of the experiment was verified by the reproducibility of the response offered by the spectrophotometric method, in which the variability of absorbance was assessed by the relative standard deviation (RSD, \%), and expressed as a percentage (Banov et al., 2006).

\section{Animals and experimental design}

Male and female Swiss mice (Mus musculus), with an average weight of $30 \mathrm{~g}$, were obtained from the Animal's House of the Universidade Federal de Mato Grosso do Sul, for use in the experiments. The animals were housed in polypropylene cages, with wood shaving as bedding. They were kept under a controlled temperature $\left(22^{\circ} \mathrm{C}\right)$, with a $12: 12 \mathrm{~h}$ light:dark schedule and free access to food and water ad libitum. All procedures and protocols followed approved guidelines for the ethical treatment of animals, according to the Ethics Committee in Animal Experimentation from the Universidade Federal de Mato Grosso do Sul (Protocol \#397/2012).

Pregnancy was determined by the detection of the copulation plug on the morning after overnight breeding, with this day being considered day zero gestation.

The animals $(\mathrm{N}=50$ female) were subdivided into 5 experimental groups $(\mathrm{N}=10$ in each group). The animals in the Control Group received saline plus DMSO (1\%) in a volume of $0.1 \mathrm{~mL} / 10 \mathrm{~g}$ (body weight, b.w.) via gavage, for at least 15 days prior to mating, and throughout the gestational period. The animals in the Pre-treatment Group received ANHMF via gavage, at a dose of $50 \mathrm{mg} / \mathrm{kg}$ (b.w.) for at least 15 days prior to mating, and until the appearance of the vaginal plug. The animals in the Organogenesis Group received ANHMF at a dose of $50 \mathrm{mg} / \mathrm{kg}$ (b.w.) via gavage, on gestational days 5-15. The animals in the Gestational Group received ANHMF at a dose of $50 \mathrm{mg} / \mathrm{kg}$ (b.w.) via gavage, throughout the gestational period (from day 1 to 18 of pregnancy). The animals in the Pre+Gestational Group received ANHMF at a dose of $50 \mathrm{mg} / \mathrm{kg}$ (b.w.) via gavage, for at least 15 days prior to mating, and throughout the gestational period.

\section{Biological assay}

\section{Reproductive performance and teratogenicity assay}

The period of gestation continued until day 18, when females were euthanized by cervical dislocation, followed by laparotomy. The maternal lung, heart, kidney, spleen, and liver were also removed and weighted. Then, a hysterectomy was performed to register the number of implantation sites and reabsorption, in addition to the number of live and 
dead fetuses, and fetal and placental weight. A systematic analysis was also performed to detect external malformations and to determine fetal sex. Based on these data, the following fertility parameters were determined: reabsorption level (No. of reabsorption x 100/No. of implantations); level of post-implantation loss (No. of implantations - No. of live fetuses $\mathrm{x}$ 100/No. of implantations); and level of external malformation (No. of malformed fetuses $\mathrm{x}$ $100 /$ No. of fetuses examined).

The offspring group was divided randomly into 2 subgroups, each containing half of the litter. The first group was fixed in Bodian's solution for visceral examination, which was performed using the incisions/microdissection proposed by Barrow and Taylor (1969) for the study of the thorax and abdomen, and using the strategic incisions proposed by Wilson (1965) for the study of the head, modified by Oliveira et al. (2009). The classification of visceral alterations was mainly based on the studies of Taylor (1986), Manson and Kang (1994), Damasceno et al. (2008), and Oliveira et al. (2009). The second subgroup was used for skeletal examination by the alizarin red technique, as described by Staples and Schnell (1964), and modified by Oliveira et al. (2009). The classifications were based on Taylor (1986), Manson et al. (1982), Damasceno et al. (2008), and Oliveira et al. (2009).

\section{Micronucleus assay of the peripheral blood}

The micronucleus test was used in this experiment to evaluate mutagenicity. A peripheral drop of blood was deposited on a glass slide previously prepared with orange acridine (1.0 $\mathrm{mg} / \mathrm{mL}$ ). A cover slip was placed over the slide, and then all slides were stored in a freezer $\left(-20^{\circ} \mathrm{C}\right)$ for a minimum period of 7 days. A total of 2000 cells/animal were examined under an epifluorescence microscope (Bioval ${ }^{\circledR}$ L-2000A), with a 40X objective, and using excitation filter $(490 \mathrm{~nm})$ and a barrier filter $(420-520 \mathrm{~nm})$.

\section{Phagocytic activity of spleen cells}

The spleen was cut into pieces with scissor, and then pressed through a stainless steel screen with $5 \mathrm{~mL}$ sterile phosphate buffer, $\mathrm{Ca}^{2+}$ and $\mathrm{Mg}^{+2}$ free, $\mathrm{pH}$ 7.4. Repeated pipetting with a Pasteur pipette was used to obtain a homogeneous cell suspension. One hundred microliters of cell suspension were immediately placed in the center of a slide that had been pre-coated with orange acridine $(1 \mathrm{mg} / \mathrm{ml})$, and then a cover slip was placed over the slide. The slides were stored in a freezer until analysis. The slides were viewed under a fluorescence microscope (Bioval, Model L 2000A) at 400 times magnification, with an excitation filter of $420-490 \mathrm{~nm}$ and an emission filter of $520 \mathrm{~nm}$. A total of 200 cells/animal were analyzed.

\section{Differential blood cell counts}

Twenty microliters of peripheral blood was used to make a smear on a histological slide. The slides were air dried, and stained by Giemsa (10\%) for $10 \mathrm{~min}$. The slides were analyzed using bright field microscopy at 1000 times magnification. A total of 100 cells/animal were analyzed, and were differentiated as lymphocytes, neutrophils, monocytes, eosinophils, and basophils. 


\section{Statistical analysis}

To compare the quantitative results of the different experimental groups investigated in this study, parametric and nonparametric tests (ANOVA/Tukey and Kruskal-Wallis/Dunn) were used depending on the distribution of data. The significance level was set to $\mathrm{P}<0.05$.

\section{RESULTS}

\section{Total flavonoid quantification in ANHMF compared to quercetin equivalents}

Samples of the ANHMF and quercetin derivative standards used and treated with NP/PEG reagents generated in UV-365 nm predominantly the presence of typical yellowishorange colored spots, indicating the presence of flavonoids (Wagner and Bladt, 2001). In addition, this fraction produced a spot by TLC with a similar retention factor (Rf) corresponding to $3-O$ - $\beta$-galactosyl-quercetin. The observed staining also demonstrated the prevalence of other derivatives of quercetin that did not correspond to available patterns. The presence of the colored spots and a retention factor corresponding to chlorogenic acid was also observed.

\section{Linearity}

The analytical methodology demonstrated linearity in the response of quercetin concentrations ranging from 2.6 to $10.7 \mathrm{mg} / \mathrm{mL}$, which is the quercetin (Sigma-Aldrich ${ }^{\circledR}$ ) secondary reference. The equation of the line and the correlation coefficient were obtained through linear regression statistics. The analytical curve expressed in $\mathrm{g} / \mathrm{mL}$ for quercetin was obtained by the method adapted from Banov et al. (2006), which is shown in Figure 1.

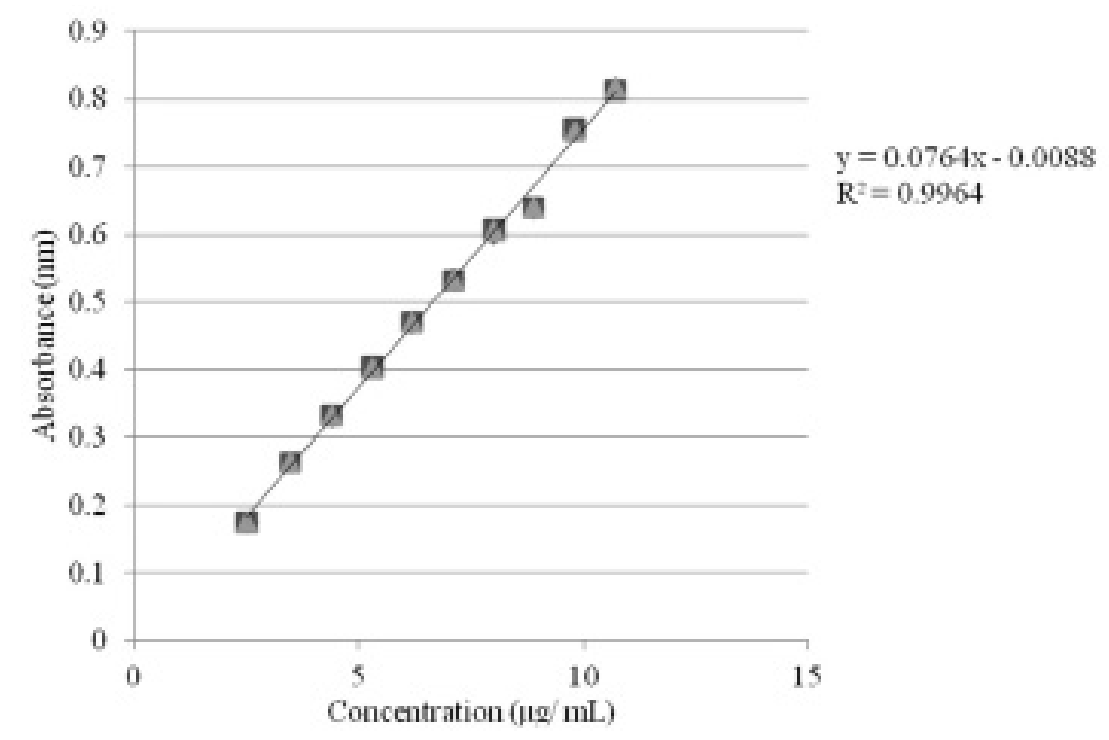

Figure 1. Calibration curve for the determination of total flavonoids. 
The equation of the straight line obtained from the calibration curve of quercetin was $y=0.0764 x-0.0088$, where $y$ is the absorbance and $x$ is the concentration of quercetin the pattern. The linearity of the method was verified by obtaining a linear correlation coefficient of 0.9964 .

\section{Total flavonoid determination of ANHMF in quercetin equivalents}

The results of the total flavonoids quantification of ANHMF equivalents in quercetin are presented in Table 1. The sample had a concentration of $9.03 \mu \mathrm{g}$ flavonoid equivalents in quercetin/mg ANHMF.

Table 1. Spectrophotometric quantification of the concentrations of the total flavonoid and quercetin equivalents
of ANHMF.
\begin{tabular}{lcccc}
\hline Absorbance $(\mathrm{nm})$ & Concentration $(\mu \mathrm{g} / \mathrm{mL})$ & Concentration $(\mu \mathrm{g} / \mathrm{mg})$ & Standard deviation & Precision SRD $(\%)$ \\
\hline 0.482 & 6.42 & 9.17 & 0.06 & \\
0.476 & 6.34 & 9.06 & \\
0.476 & 6.34 & 9.06 & \\
0.473 & 6.30 & 9.01 & \\
0.472 & 6.29 & 9.00 & \\
0.469 & 6.25 & 8.93 & \\
0.475 & 6.33 & 9.04 & \\
0.472 & 6.29 & 9.00 & \\
0.473 & 6.30 & 9.00 & \\
Mean & 6.32 & 9.03 & \\
\hline
\end{tabular}

$\mathrm{ANHMF}=$ Annona nutans hydromethanolic fraction; $\mathrm{SRD}=$ relative standard deviation.

\section{Accuracy}

The relative standard deviation did not exceed the threshold value of $5 \%(0.70 \%)$, indicating a decline in the dispersion of spectrophotometric responses (absorbance at $429 \mathrm{~nm}$ ) (Banov et al., 2006).

\section{Evaluation of reproductive performance and embryo-fetal development}

Table 2 shows the maternal body weight of mice in all of the experimental groups. There was no significant weight gain or loss during the experiments. Table 3 shows the absolute and relative weight of the heart, lung, kidney, and liver. Except for the kidney, the absolute weight in the Gestational Group, and the absolute and relative weight of the lung in the Pre + Gestational Group, increased $(\mathrm{P}<0.05)$ compared to the Control group. No significant alteration $(\mathrm{P}>0.05)$ was found for the weight of any other organ.

There was no significant difference between the parameters related to fertility and fetal development $(\mathrm{P}>0.05)$, including the number of implants, the total number of reabsorptions and reabsorption rate, the number of dead fetuses, fetal viability, and placental weight (Table 4). There appeared to be a reduction in the number of live fetuses in the ANHMF exposed groups, but this phenomenon was only statistically significant in the Pre + Gestational Group $(\mathrm{P}<0.05)$. In addition, fetus weight increased $(\mathrm{P}<0.05)$ in the Pre-treatment, Organogenesis, and Pre+Gestational Groups exposed to ANHMF compared to the Control Group (Table 4). 
Table 2. Initial weight, final weight, and weight gain during the treatment period.

\begin{tabular}{lccr}
\hline Experimental Group & \multicolumn{1}{c}{ Parameter } \\
\cline { 2 - 4 } & Initial weight & Final weight & Weight gain \\
\hline Control & $28.84 \pm 0.21$ & $47.73 \pm 1.63$ & $18.89 \pm 1.73$ \\
Pre-treatment & $27.66 \pm 0.31$ & $47.89 \pm 1.70$ & $20.23 \pm 1.64$ \\
Organogenesis & $27.32 \pm 0.17$ & $45.72 \pm 1.33$ & $18.40 \pm 1.36$ \\
Gestational & $28.62 \pm 0.28$ & $42.87 \pm 1.43$ & $14.24 \pm 1.28$ \\
Pre+gestational & $27.57 \pm 0.29$ & $42.05 \pm 1.99$ & $14.48 \pm 2.15$ \\
\hline
\end{tabular}

Results are reported as means \pm standard error $(\mathrm{P}<0.05$, ANOVA/Tukey).

Table 3. Relative and absolute female-organ weights during the treatment period.

\begin{tabular}{|c|c|c|c|c|}
\hline \multirow[t]{3}{*}{ Experimental group } & \multicolumn{4}{|c|}{ Parameter } \\
\hline & \multicolumn{4}{|c|}{ Absolute weight (g) } \\
\hline & Heart & Lung & Kidney & Liver \\
\hline Control & $0.1520 \pm 0.0071^{\mathrm{a}}$ & $0.1820 \pm 0.0065^{\mathrm{a}, \mathrm{b}}$ & $0.3610 \pm 0.0124^{\mathrm{a}}$ & $2.1650 \pm 0.0815^{\mathrm{a}}$ \\
\hline Pre-treatment & $0.1360 \pm 0.0047^{a}$ & $0.1820 \pm 0.0063^{\mathrm{a}, \mathrm{b}}$ & $0.3480 \pm 0.0081^{\mathrm{a}, \mathrm{b}}$ & $2.1730 \pm 0.0735^{\mathrm{a}}$ \\
\hline Organogenesis & $0.1500 \pm 0.0049^{\mathrm{a}}$ & $0.1810 \pm 0.0060^{\mathrm{a}, \mathrm{b}}$ & $0.3420 \pm 0.0092^{\mathrm{a}, \mathrm{b}}$ & $1.8960 \pm 0.0598^{\mathrm{a}}$ \\
\hline Gestational & $0.1380 \pm 0.0044^{\mathrm{a}}$ & $0.1600 \pm 0.0042^{\mathrm{a}}$ & $0.3180 \pm 0.0059^{\mathrm{b}}$ & $1.9230 \pm 0.0797^{\mathrm{a}}$ \\
\hline Pre+gestational & $0.1420 \pm 0.0044^{\mathrm{a}}$ & $0.1940 \pm 0.0049^{b}$ & $0.3440 \pm 0.0088^{\mathrm{a}, \mathrm{b}}$ & $2.0050 \pm 0.0747^{\mathrm{a}}$ \\
\hline \multirow[t]{2}{*}{ Experimental group } & \multicolumn{4}{|c|}{ Relative weight (g) } \\
\hline & Heart & Lung & Kidney & Liver \\
\hline Control & $0.0032 \pm 0.0002^{\mathrm{a}}$ & $0.0038 \pm 0.0001^{\mathrm{a}}$ & $0.0076 \pm 0.0002^{\mathrm{a}}$ & $0.0455 \pm 0.0017^{\mathrm{a}}$ \\
\hline Pre-treatment & $0.0028 \pm 0.0001^{\mathrm{a}}$ & $0.0038 \pm 0.0002^{\mathrm{a}}$ & $0.0073 \pm 0.0002^{\mathrm{a}}$ & $0.0455 \pm 0.0011^{\mathrm{a}}$ \\
\hline Organogenesis & $0.0032 \pm 0.0001^{\mathrm{a}}$ & $0.0040 \pm 0.0002^{\mathrm{a}, \mathrm{b}}$ & $0.0075 \pm 0.0003^{\mathrm{a}}$ & $0.0417 \pm 0.0016^{\mathrm{a}}$ \\
\hline Gestational & $0.0032 \pm 0.0002^{\mathrm{a}}$ & $0.0037 \pm 0.0001^{\mathrm{a}}$ & $0.0075 \pm 0.0002^{\mathrm{a}}$ & $0.0450 \pm 0.0017^{\mathrm{a}}$ \\
\hline Pre+gestational & $0.0034 \pm 0.0002^{\mathrm{a}}$ & $0.0047 \pm 0.0003^{\mathrm{b}}$ & $0.0083 \pm 0.0003^{\mathrm{a}}$ & $0.0482 \pm 0.0017^{\mathrm{a}}$ \\
\hline
\end{tabular}

Results are reported as means \pm standard error. Different letters mean significant differences $(\mathrm{P}<0.05, \mathrm{ANOVA} /$ Tukey $)$.

Table 4. Parameters related to fertility and fetal development during the treatment period.

\begin{tabular}{|c|c|c|c|c|c|}
\hline \multirow[t]{2}{*}{ Parameter } & \multicolumn{5}{|c|}{ Experimental group } \\
\hline & Control & Pre-treatment & Organogenesis & Gestational & Pre+gestational \\
\hline Fetuses analyzed (No.) & 109 & 100 & 99 & 81 & 59 \\
\hline Implants $^{2}$ (No.) & $11.40 \pm 1.29^{\mathrm{a}}$ & $10.40 \pm 0.87^{\mathrm{a}}$ & $10.50 \pm 1.07^{\mathrm{a}}$ & $8.80 \pm 1.15^{\mathrm{a}}$ & $6.50 \pm 1.56^{\mathrm{a}}$ \\
\hline Reabsorption $^{2}$ (No.) & $0.50 \pm 0.22^{\mathrm{a}}$ & $0.20 \pm 0.13^{\mathrm{a}}$ & $0.40 \pm 0.30^{\mathrm{a}}$ & $0.60 \pm 0.22^{\mathrm{a}}$ & $0.60 \pm 0.22^{\mathrm{a}}$ \\
\hline Reabsorption rate $^{2}(\%)$ & $4.57 \pm 1.97^{\mathrm{a}}$ & $2.22 \pm 1.48^{\mathrm{a}}$ & $3.00 \pm 2.13^{\mathrm{a}}$ & $6.65 \pm 2.73^{\mathrm{a}}$ & $9.20 \pm 3.44^{\mathrm{a}}$ \\
\hline Live fetuses $^{2}$ (No.) & $10.90 \pm 1.29^{\mathrm{a}}$ & $10.00 \pm 0.99^{\mathrm{a}, \mathrm{b}}$ & $9.90 \pm 0.97^{\mathrm{a}, \mathrm{b}}$ & $8.10 \pm 0.97^{\mathrm{a}, \mathrm{b}}$ & $5.90 \pm 1.52^{b}$ \\
\hline Dead fetuses ${ }^{1}$ (No.) & $0.10 \pm 0.10^{\mathrm{a}}$ & $0.20 \pm 0.13^{\mathrm{a}}$ & $0.20 \pm 0.13^{\mathrm{a}}$ & $0.10 \pm 0.10^{\mathrm{a}}$ & $0.00 \pm 0.00^{\mathrm{a}}$ \\
\hline Rate of post-implantation ${ }^{2}(\%)$ & $10.45 \pm 1.29^{\mathrm{a}}$ & $9.45 \pm 0.85^{\mathrm{a}}$ & $9.55 \pm 1.08^{\mathrm{a}}$ & $7.86 \pm 1.17^{\mathrm{a}}$ & $12.08 \pm 3.25^{\mathrm{a}}$ \\
\hline Fetal viability ${ }^{2}$ & $95.43 \pm 1.97^{\mathrm{a}}$ & $94.36 \pm 2.66^{\mathrm{a}}$ & $95.22 \pm 2.80^{\mathrm{a}}$ & $94.02 \pm 2.53^{\mathrm{a}}$ & $90.80 \pm 3.44^{\mathrm{a}}$ \\
\hline Fetuses weight $(\mathrm{g})^{2}$ & $1.04 \pm 0.01^{\mathrm{a}}$ & $1.16 \pm 0.01^{\mathrm{c}}$ & $1.18 \pm 0.01^{\mathrm{c}}$ & $1.09 \pm 0.01^{\mathrm{a}, \mathrm{b}}$ & $1.12 \pm 0.02^{\mathrm{b}, \mathrm{c}}$ \\
\hline Placenta weight $(\mathrm{g})^{1}$ & $0.08 \pm 0.00^{\mathrm{a}, \mathrm{b}}$ & $0.09 \pm 0.00^{\mathrm{a}}$ & $0.08 \pm 0.00^{\mathrm{b}}$ & $0.08 \pm 0.00^{\mathrm{b}}$ & $0.08 \pm 0.00^{\mathrm{b}}$ \\
\hline
\end{tabular}

Results are reported as means \pm standard error. Different letters indicate significant differences $\left(\mathrm{P}<0.05,{ }^{1}\right.$ KruskalWallis/Dunn, ${ }^{2}$ ANOVA/Tukey).

Table 5 shows the external abnormalities and variations recorded on the progeny of the different experimental groups. Observed malformations included hydronephrosis and the absence or reduction of phalange ossifications. However, similar frequencies of these malformations were obtained in all groups $(\mathrm{P}>0.05)$. 
Table 5. Abnormalities and variations found in the progeny from the different experimental groups.

\begin{tabular}{|c|c|c|c|c|c|}
\hline \multirow[t]{2}{*}{ Parameters } & \multicolumn{5}{|c|}{ Experimental group } \\
\hline & Control & Pre-treatment & Organogenesis & Gestational & Pre+gestational \\
\hline \multicolumn{6}{|l|}{ External malformation } \\
\hline Fetuses analyzed (No.) & 109 & 110 & 99 & 81 & 59 \\
\hline$\% \mathrm{MF}^{*}$ & $0.00 \pm 0.00$ & $0.00 \pm 0.00$ & $0.00 \pm 0.00$ & $0.00 \pm 0.00$ & $0.00 \pm 0.00$ \\
\hline \multicolumn{6}{|l|}{ Visceral malformation } \\
\hline Fetuses analyzed (No.) & 52 & 47 & 49 & 38 & 28 \\
\hline Hydronephrosis & 10 & 9 & 7 & 4 & 5 \\
\hline$\% \mathrm{MF}^{*}$ & $14.17 \pm 7.64$ & $17.33 \pm 6.06$ & $18.93 \pm 6.35$ & $10.00 \pm 5.66$ & $22.62 \pm 12.20$ \\
\hline \multicolumn{6}{|l|}{ Skeletal malformation } \\
\hline Fetuses analyzed (No.) & 57 & 53 & 50 & 43 & 31 \\
\hline Absence/reduction of phalanges ossification & 55 & 34 & 31 & 38 & 21 \\
\hline$\% \mathrm{MF}^{*}$ & $93.57 \pm 5.05$ & $58.08 \pm 13.73$ & $61.67 \pm 14.50$ & $86.00 \pm 9.91$ & $66.67 \pm 16.67$ \\
\hline
\end{tabular}

$\% \mathrm{MF}^{*}=$ mean value of malformation percentage \pm standard error $(\mathrm{P}<0.05$, Kruskal-Wallis $)$.

\section{Micronucleus test in peripheral blood}

Table 6 shows the frequency, mean, and standard deviation of the micronucleus test in the peripheral blood during days 16 to 18 of pregnancy. There was no significant difference between the Control and treated groups regarding these data. In addition, for the Pre-treatment Group, the peripheral blood samples were also collected from days 1 to 3 of pregnancy (i.e., a period of 3 days after ANHMF administration). This analysis produced a total frequency of 10,11 , and 10 micronuclei and a mean micronuclei frequency of $0.90 \pm 0.23,1.00 \pm 0.26$, and $1.00 \pm 0.30$ for days 1,2 , and 3 of pregnancy, respectively. These values were similar to those observed for the micronucleus frequencies at days 16 to 18 of pregnancy, which indicates absence of mutagenic activity.

Table 6. Frequency of micronuclei in the peripheral blood.
\begin{tabular}{lccccccr}
\hline Experimental group & \multicolumn{3}{c}{ Micronucleus frequency $^{1}$} & & \multicolumn{3}{c}{ Mean value \pm standard deviation } \\
\cline { 2 - 7 } & $D 16$ & $D 17$ & $D 18$ & & $D 16$ & $D 17$ & $D 18$ \\
\hline Control & 19 & 24 & 22 & $1.90 \pm 0.28$ & $2.40 \pm 0.30$ & $2.20 \pm 0.20$ \\
Pre-treatment & 18 & 18 & 24 & $1.80 \pm 0.25$ & $1.80 \pm 0.20$ & $2.40 \pm 0.27$ \\
Organogenesis & 23 & 19 & 23 & $2.30 \pm 0.26$ & $1.90 \pm 0.23$ & $2.30 \pm 0.30$ \\
Gestational & 17 & 19 & 19 & $1.70 \pm 0.21$ & $1.90 \pm 0.28$ & $1.90 \pm 0.18$ \\
Pre+gestational & 21 & 19 & 22 & $2.10 \pm 0.24$ & $1.90 \pm 0.10$ & $2.20 \pm 0.25$ \\
\hline
\end{tabular}

${ }^{1}$ Total micronucleus frequency in 20,000 cells analyzed (2000 cell/animal). ${ }^{2}$ Micronucleus mean value in 20,000 cells analyzed (2000 cell/animal). ( $\mathrm{P}<0.05$, ANOVA/Tukey).

\section{Differential blood cell counts}

Table 7 presents the differential blood cell counts for the Control and ANHMF exposed groups. A tendency toward a discrete eosinophilia was observed; however, the blood cell values of all groups were similar $(\mathrm{P}>0.05)$.

\section{Phagocytic activity in the spleen}

Table 8 shows the total cells analyzed, means \pm standard error, and the percentage of 
cells with and without evidence of phagocytosis in all study groups. There was no significant difference between the Control and ANHMF treated groups. These data on differential blood cell counts indicated that, under these experimental conditions, ANHMF does not present immunomodulatory activity.

Table 7. Differential analysis of peripheral blood cells in pregnant female mice during the treatment period.

\begin{tabular}{lcrrrrr}
\hline Parameter & \multicolumn{5}{c}{ Experimental group } \\
\cline { 2 - 7 } & Reference value* & \multicolumn{1}{c}{ Control } & Pre-treatment & Organogenesis & Gestational & Pre+gestational \\
\hline Lymphocyte & $55-95 \%$ & $71.40 \pm 0.60$ & $71.80 \pm 0.97$ & $70.30 \pm 0.75$ & $72.10 \pm 0.94$ & $71.60 \pm 0.98$ \\
Neutrophil & $10-40 \%$ & $26.90 \pm 0.69$ & $26.00 \pm 0.91$ & $27.30 \pm 0.73$ & $25.70 \pm 0.94$ & $26.30 \pm 0.92$ \\
Eosinophil & $0-0.4 \%$ & $1.10 \pm 0.23$ & $1.50 \pm 0.27$ & $1.70 \pm 0.21$ & $1.60 \pm 0.34$ & $1.50 \pm 0.34$ \\
Monocytes & $0-3.5 \%$ & $0.70 \pm 0.16$ & $0.60 \pm 0.22$ & $0.70 \pm 0.21$ & $0.60 \pm 0.16$ & $0.60 \pm 0.30$ \\
Basophil & $0-0.3 \%$ & $0.00 \pm 0.00$ & $0.00 \pm 0.00$ & $0.00 \pm 0.00$ & $0.00 \pm 0.00$ & $0.00 \pm 0.00$ \\
\hline
\end{tabular}

Results are reported as means \pm standard error. *Ishii et al. (2011). $(\mathrm{P}<0.05$, ANOVA/Tukey).

\begin{tabular}{|c|c|c|c|c|c|c|c|}
\hline \multirow[t]{2}{*}{ Experimental group } & \multirow{2}{*}{$\begin{array}{c}\text { No. of } \\
\text { cells analyzed }\end{array}$} & \multicolumn{3}{|c|}{ Total cells without evidence of phagocytosis } & \multicolumn{3}{|c|}{ Total cells with evidence of phagocytosis } \\
\hline & & Total No. & Means $\pm \mathrm{SE}$ & Percentage $(\%)$ & Total No. & Means $\pm \mathrm{SE}$ & Percentage $(\%)$ \\
\hline Control & 100 & 977 & $97.70 \pm 0.26$ & 97.7 & 23 & $2.30 \pm 0.26$ & 2.3 \\
\hline Pre-treatment & 100 & 981 & $98.10 \pm 0.48$ & 98.1 & 19 & $1.90 \pm 0.48$ & 1.9 \\
\hline Organogenesis & 100 & 973 & $97.30 \pm 0.26$ & 97.3 & 27 & $2.70 \pm 0.26$ & 2.1 \\
\hline Gestational & 100 & 977 & $97.70 \pm 0.26$ & 97.7 & 23 & $2.30 \pm 0.26$ & 2.3 \\
\hline Pre+gestational & 100 & 975 & $97.50 \pm 0.27$ & 97.5 & 25 & $2.50 \pm 0.27$ & 2.5 \\
\hline
\end{tabular}

$\mathrm{SE}=$ standard error. Results are reported as means \pm standard error $(\mathrm{P}<0.05$, ANOVA/Tukey $)$.

\section{DISCUSSION}

Medicinal plants are used by various cultures, and are assumed to be safe and low cost, which enhances their use by people. Therefore, the safety and efficacy of using these plants should be proven scientifically, to validate their use as herbal medicine (Calixto, 2000).

Plants belonging to the Annonaceae family contain important compounds, such as diterpenes with antitumor activity, oliverine with antiparkinsonian activity, and liriodenine with antitumor, antibacterial, and antifungal properties (Zhang et al., 2004). Moreover, the leaves of $A$. dioica have anti-inflammatory, hypoglycemic, antiproliferative, and antioxidant effects. This antioxidant activity might be associated with the presence of flavonoids (Formagio et al., 2013). Traditional preparations of the leaves of A. muricata, A. squamosa, and A. reticulata have been used as sedatives, as digestive aids, and as aphrodisiacs; however, this use has been associated with atypical Parkinson syndrome (Champy et al., 2004; Caparros-Lefebvre and Steele, 2005). In addition, one study shows that $A$. squamosa extract affects the reproductive performance of female rats (Damasceno et al., 2002).

Therefore, the primary aim of the present study was to investigate whether different windows of exposure to ANHMF during pregnancy might interfere with the reproductive performance of female Swiss mice. Exposed animals received the ANHMF at 4 periods of exposure. First, ANHMF was given prior to mating (Pre-treatment group), to assess the effects 
of ANHMF on gamete maturation and fertilization. Second, ANHMF was given during organogenesis (Organogenesis Group), to assess the effects on teratogenicity. Third, it was given throughout the gestational period (Gestational Group), to assess its effects on pre-implantation and embryo-fetal development. Finally, it was given for a combination of the Pre-treatment plus Gestational treatment (Pre+Gestational Group), to evaluate sub chronic cumulative effects.

ANHMF exposure did not affect maternal weight gain, the relative weight of the organs, or placental weight. Therefore, we suggest that, under these experimental conditions, ANHMF is not toxic, as no clinical signals of maternal toxicity were observed (Damasceno et al., 2002). As the number of implants, reabsorptions, dead fetuses, fetal viability, reabsorption rate, and fetus morphological analyses (visceral and skeletal) were similar between the control and treated groups, we also suggest that ANHMF does not interfere in the progress of embryofetal development, or cause any lethality. Although the fetus weight of some ANHMF exposed animals differed to control group, this parameter might vary with litter size. In contrast to that proposed by Vohora et al. (1975) and Mishra et al. (1979), our study demonstrates that plants from the Annonaceae family do not exhibit anti-ovulatory or abortive activity. These results indicate that ANHMF is safe to use during pre-pregnancy and/or throughout pregnancy. As previously documented for $A$. squamosa (Damasceno et al., 2002), our results confirm that A. nutans does not influence embryo implantation or the reproductive performance of pregnant females. Even though we did not measure hormone levels, we suggest that endometrial integrity was maintained, since anti-implantation effects were not observed (Damasceno and Lemonica, 1999). Furthermore, we found that $A$. nutans was not correlated with any external, skeletal, and/or visceral malformations, indicating the absence of teratogenicity. Although hydronephrosis and reduced/absence of phalange ossification was documented in all experimental groups, we assumed that these were normal variants, based on the descriptions of Kimmel and Wilson (1973), Taylor (1986), and Szabo (1989), who suggested that some parameters may be considered less relevant when recorded in both the control and treatment groups. For instance, skeletal variation may arise spontaneously in fetuses and newborns (Taylor, 1986) or may be caused by drugs (Kimmel and Wilson, 1973); however, in the present study we did not find significant alteration in this parameter.

In this study, the micronuclei frequency was not significant, which confirms the nontoxicity of ANHMF. In contrast, mutagenic and teratogenic events are related, as both arise from DNA-based changes (Oliveira et al., 2009). In general, the low frequency of micronuclei in this study may be correlated to two facts: 1) the substance tested did not induce chromosomal damage or 2) the micronucleus-induced treatment was arrested by the spleen through splenic phagocytosis. Our study shows that the frequency of splenic phagocytosis was similar between the control and ANHMF exposed animals, with this result reinforcing that ANHMF does not cause genetic toxicity. The differential cell count of the peripheral blood corroborated this finding, showing that ANHMF treatment does not promote immunomodulation. Based on this result, we inferred that there is no effective migration of monocytes from the bloodstream to the spleen; thus, macrophages did not cause any increase in the number of phagocytosis in this organ. It has been well established in the literature (Ishii et al., 2011) that circulating monocytes are able to move to the tissues, and are called macrophages in the spleen. However, these cells only become active and participate in phagocytosis when necessary. If an organism does not need this form of defense, the cells remain present, but without exerting any phagocytic activity. 
The literature does not present data indicating that $A$. nutans is mutagenic. However, some authors have evaluated the antimutagenic activity of $A$. squamosa (Chen et al., 2012) and $A$. crassiflora (Vilar et al., 2008; Dragano et al., 2010). In addition, A. squamosa presents antitumor activity against human hepatoma cells, with this property potentially being attributed to the presence of acetogenins, which is the main bioactive compound observed in this species (Chen et al., 2012). Furthermore, abnormalities of the spermatozoa may be correlated to alterations in male offspring that determine the appearance of male-mediated teratogenesis and/or alterations in reproductive performance (Rabelo-Gay et al., 1991). Hence, the absence of this condition in the present study confirms that Annona does not interfere with mouse reproductive performance or embryo-fetal development. Furthermore, A. crassiflora, which also belongs to the genus Annona, did not show any mutagenic or genotoxic effects in Escherichia coli or Salmonella typhimurium tests (Vilar et al., 2008). Moreover, A. muricata presents antioxidant properties, due to the presence of the glycoside flavonoids and chlorogenic acid, which stimulate pro-mitotic growth factor in human keratinocytes (Nawwar et al., 2012).

Our results show that ANHMF primarily contains quercetin derivatives and phenolic acids (cinnamic acid derivatives, such as chlorogenic acid). These substances play important roles in disease prevention. Flavonoids and phenolic acids, for instance, are known to present antioxidant, anti-inflammatory (Coutinho et al., 2009), and chemopreventive activity (Venkatesh et al., 2002). Furthermore, previous studies have shown that the flavonoid-3-Oglycosides derivatives (i.e., quercitrin [quercetin-3-O-rhamnoside], rutin [quercetin-3-O-rutinoside], robinin [kaempferol-3- $O$-galactoside-rhamnoside-7- $O$-rhamnoside], quercetin-3- $O$ $\beta$-D-galactopyranoside, methyl gallate, gallic acid; Brown, 1980; Sannomiya et al., 2007) do not exhibit any mutagenic activity. The free hydroxyl group at C-3 is the most important group that determines the mutagenic activity of flavonoids (Brown, 1980; Sahu et al., 1981), whereas the 3-O-glycoside flavonoid derivatives are devoid of mutagenic activity. ANHMF contains substance that have similar retention factors (Rf) to 3-O- $\beta$-galactosyl-quercetin and others quercetin glycoside derivatives which could explain its lack of mutagenicity.

The hydromethanolic fraction assessed in this study is predominantly characterized by polar compounds. Since the methanolic extract obtained by percolation (see methodology), and it was previously subjected partition with less polar solvents, the resultant fraction has similar chemical constitution of popular beverages obtained by infusion and decoction.

In conclusion, to our knowledge, this study is the first report in the peer-reviewed literature that evaluates the effects of ANHMF on pregnant mice. We suggest that, under these experimental conditions, ANHMF does not interfere with reproductive performance, embryofetal development, or the frequency of genomic lesions at a chromosomal level, and does not promote immunomodulation activity.

\section{ACKNOWLEDGMENTS}

Research supported by FUNDECT (Edital Chamada FUNDECT \#5/2011-PPPProcesso \#23/200.702/2012-Termo de Outorga \#0207/12; Edital Chamada FUNDECT/CNPq \#06/2011-PRONEM); FAPEMIG (Programa Pesquisador Mineiro \#PPM-00108-11), and FAPEMIG (Programa Pesquisador Mineiro \#PPM-00108-11). The authors J.M. Siqueira and M.C. Vieira acknowledge CNPq for grant support. Authors F.J.L. Santos, C.A. Gonçalves, and 


\section{N.L. Silva acknowledge CAPES and CNPq for grant support.}

\section{REFERENCES}

Banov D, Baby AR, Bosco LM and Kaneko TM (2006). Caracterização do extrato seco de Ginkgo biloba L. em formulações de uso tópico. Acta Farm. Bonaer. 25: 219-224.

Barrow MV and Taylor WJ (1969). A rapid method for detecting malformations in rat fetuses. J. Morphol. 127: 291-305.

Brown JP (1980). A review of the genetic effects of naturally occurring flavonoids, anthraquinones and related compounds. Mutat. Res. 75: 243-277.

Calixto JB (2000). Efficacy, safety, quality control, marketing and regulatory guidelines for herbal medicines (phytotherapeutic agents). Braz. J. Med. Biol. Res. 33: 179-189.

Caparros-Lefebvre D and Steele J (2005). Atypical parkinsonism on Guadeloupe, comparison with the parkinsonismdementia complex of Guam, and environmental toxic hypotheses. Environ. Toxicol. Pharmacol. 19: 407-413.

Champy P, Höglinger GU, Feger J, Gleye C, et al. (2004). Annonacin, a lipophilic inhibitor of mitochondrial complex I, induces nigral and striatal neurodegeneration in rats: possible relevance for atypical parkinsonism in Guadeloupe. $J$. Neurochem. 88: 63-69.

Chen Y, Xu SS, Chen JW, Wang Y, et al. (2012). Anti-tumor activity of Annona squamosa seeds extract containing annonaceous acetogenin compounds. J. Ethnopharmacol. 142: 462-466.

Coutinho MAS, Muzitano MF and Costa SS (2009). Flavonoides: potenciais agentes terapêuticos para o processo inflamatório. Rev. Virtual Quim. 1:241-256.

Damasceno DC and Lemonica IP (1999). Embryotoxicity and anti-implantation effects of Rosemary (Rosmarinus officinalis L.) extract in pregnant rats within preimplantation period. Rev. Bras. Toxicol. 12: 47-54.

Damasceno DC, Volpato GT, Sartori TC, Rodrigues PF, et al. (2002). Effects of Annona squamosa extract on early pregnancy in rats. Phytomedicine 9: 667-672.

Damasceno DC, Kempinas WG, Volpato GT and Consoni M (2008). Anomalias Congênitas: Estudos Experimentais. Coopmed Editora Médica, Belo Horizonte.

Dragano NR, de Venancio VP, Paula FB, Della LF, et al. (2010). Influence of Marolo (Annona crassiflora Mart.) pulp intake on the modulation of mutagenic/antimutagenic processes and its action on oxidative stress in vivo. Plant Foods Hum. Nutr. 65: 319-325.

Formagio AS, Kassuya CA, Neto FF, VolobuffCR, et al. (2013). The flavonoid content and antiproliferative, hypoglycaemic, anti-inflammatory and free radical scavenging activities of Annona dioica St. Hill. BMC Complement. Altern. Med. 13: 14 .

Gonçalves CA, Siqueira JM, Carollo CA, Mauro MO, et al. (2013). Gestational exposure to Byrsonima verbascifolia: teratogenicity, mutagenicity and immunomodulation evaluation in female Swiss mice. J. Ethnopharmacol. 150: 843850.

Ishii PL, Prado CK, Mauro MO, Carreira CM, et al. (2011). Evaluation of Agaricus blazei in vivo for antigenotoxic, anticarcinogenic, phagocytic and immunomodulatory activities. Regul. Toxicol. Pharmacol. 59: 412-422.

Kimmel CA and Wilson JG (1973). Skeletal deviations in rats: malformations or variations? Teratology 8: 309-315.

Lapa AJ, Souccar C, Lima-Landman MTR and Godinho RO (2004). Farmacologia e Toxicologia de Produtos Naturais. In: Farmacognosia: da Planta ao Medicamento (Simões CMO, Schenkel EP, Gosmann G and Mello JCP, eds.). Editora da UFRGS/Editora da UFSC, Porto Alegre, 247-262.

Lebeouf M, Cavé A, Bhaumik PK and Mukherjee B (1980). The phytochemistry of the annonaceae. Phytochemistry 21: 2783-2813.

Manson JM and Kang YJ (1994). Test Methods for Assessing Female Reproductive and Developmental Toxicology. In: Principles and Methods of Toxicology (Hayes AW, ed.). Raven Press, New York, 989-1038.

Manson JM, Zenick H and Costlow RD (1982). Teratology Test Methods for Laboratory Animals. In: Principles and Methods of Toxicology (Hayes AW, ed.). Raven Press, New York, 141-185.

McElhatton PR (1999). Principles of Teratogenicity. Current Obstet. Gynaecol. 9: 163-169.

Mishra A, Dogra JV, Singh JN and Jha OP (1979). Post-coital antifertility activity of Annona squamosa and Ipomoea fistulosa. Planta Med. 35: 283-285.

Nawwar M, Ayoub N, Hussein S, Hashim A, et al. (2012). A flavonol triglycoside and investigation of the antioxidant and cell stimulating activities of Annona muricata Linn. Arch. Pharm. Res. 35: 761-767.

Oliveira RJ, Salles MJ, da Silva AF, Kanno TY, et al. (2009). Effects of the polysaccharide $\beta$-glucan on clastogenicity and teratogenicity caused by acute exposure to cyclophosphamide in mice. Regul. Toxicol. Pharmacol. 53: 164-173.

Rabelo-Gay MN, Rodrigues MALR and Monteleone-Neto R (1991). Mutagênese, Teratogênese e Carcinogênese: Métodos 
e Critérios de Avaliação. Sociedade Brasileira de Genética/Revista Brasileira, Ribeirão Preto.

Sahu RK, Basu R and Sharma A (1981). Genetic toxicological of some plant flavonoids by the micronucleus test. Mutat. Res. 89: 69-74.

Sannomiya M, Cardoso CR, Figueiredo ME, Rodrigues CM, et al. (2007). Mutagenic evaluation and chemical investigation of Byrsonima intermedia A. Juss. leaf extracts. J. Ethnopharmacol. 112: 319-326.

Staples RE and Schnell VL (1964). Refinements in rapid clearing technic in the koh-alizarin red s method for fetal bone. Stain Technol. 39: 61-63.

Szabo KT (1989). Congenital Malformations in Laboratory and Farm Animals. Academic Press, San Diego.

Taylor P (1986). Practical Teratology. Academic Press, New York.

Venkatesh V, Sharma JD and Kamal R (2002). A comparative study of effect of alcoholic extracts of Sapindus emarginatus, Terminalia belerica, Cuminum cyminum and Allium cepa on reproductive organs of male albino rats. Asian J. Exp. Sci. 16: 51-63.

Vilar JB, Ferreira FL, Ferri PH, Guillo LA, et al. (2008). Assessment of the mutagenic, antimutagenic and cytotoxic activities of ethanolic extract of araticum (Annona crassiflora Mart. 1841) by micronucleus test in mice. Braz. J. Biol. 68: 141-147.

Vohora SB, Kumar I and Naqvi SA (1975). Phytochemical, pharmacological, antibacterial and anti-ovulatory studies on Annona squamosa. Planta Med. 28: 97-100.

Wagner H and Bladt S (2001). Plant Drug Analysis: A thin Layer Chromatography Atlas. 2nd edn. Springer, Berlin.

Welsch F (1992). In vitro approaches to the elucidation of mechanisms of chemical teratogenesis. Teratology 46: 3-14.

Wilson JG (1965). Methods for Administering Agents and Detecting Malformations in Experimental Animals. In: Teratology: Principles and Techniques (Wilson JG and Warkany J, eds.). The University of Chicago Press, Chicago, 262-277.

Yuan SS, Chang HL, Chen HW, Kuo FC, et al. (2006). Selective cytotoxicity of squamocin on T24 bladder cancer cells at the S-phase via a Bax-, Bad-, and caspase-3-related pathways. Life Sci. 78: 869-874.

Zhang YH, Peng HY, Xia GH, Wang MY, et al. (2004). Anticancer effect of two diterpenoid compounds isolated from Annona glabra Linn. Acta Pharmacol. Sin. 25: 937-942. 